\title{
Narrativas de violências praticadas por parceiros íntimos contra mulheres
}

\author{
Narratives of intimate partner violence practiced against women
}

Leides Barroso Azevedo Moura ${ }^{1}$

Fernando Lefevre ${ }^{2}$

Valter Moura $^{3}$

${ }^{1}$ Ciências da Saúde, Universidade de Brasília. Campi Universitário, Asa Norte. 70.910-900 Brasilia DF.lmoura@unb.br

${ }^{2}$ Departamento de Prática de Saúde Pública, Faculdade de Saúde Pública, Universidade de São Paulo. ${ }^{3}$ Igreja Presbiteriana de Brasília

\begin{abstract}
Research was conducted with women aged 15 to 49 living in an economically vulnerable area of the Brazilian state capital on the experience of victims of Intimate Partner Violence (IPV). The study adopted a qualitative technique called Collective Subject Discourse. During the interviews in their homes between February and July, 195 women reported incidents of violence throughout their lives. The discourses were grouped by similar violence using the CSD technique and organized into 7 major categories based on 395 key words; i) IPV Engineering ( $N=114$; $58.5 \%)$; ii) Rape of vulnerable sex ( $N=77 ; 39.5 \%)$; iii) Silent or silenced violence $(N=43 ; 21 \%)$; iv) Years of Suffering $(N=43 ; 21 \%) ; v)$ New time despite the suffering $(\mathrm{N}=39 ; 20 \%)$; vi) Talking about violence $(N=35 ; 18 \%)$; Violence is a language $(N=34 ; 17.4 \%)$. Three reports with the highest prevalence, entitled "IPV Engineering," are presented in full in this work. The narratives of violence revealed show the strength of vulnerability and abuse suffered by women and the existence of multiple dynamics of violence in intimate affective relationships.
\end{abstract}

Key words Gender-based violence, Intimate partner violence
Resumo Foi realizada uma pesquisa com mulheres de 15 a 49 anos moradoras de uma área de vulnerabilidade social da capital brasileira para conhecer os discursos femininos sobre suas vivências de violências praticadas por parceiros intimos. Foi utilizada uma abordagem qualitativa e técnica do Discurso do Sujeito Coletivo. Durante entrevistas realizadas em seus domicílios no período de fevereiro a julho de 2007, 195 mulheres narraram, episódios de violências sofridas ao longo da vida. As entrevistas geraram 32 Discursos do Sujeito Coletivo que foram construídos a partir de 395 expressões-chaves agrupadas em sete blocos temáticos: i) Engenharia das VPI $(N=114$; 58,5\%); ii) Histórias de estupro de vulneráveis ( $N=77 ; 39,5 \%)$; iii) Violências silenciosas ou silenciadas ( $N=43 ; 22 \%) ; i v)$ Anos potenciais de vida sofrida ( $N=43 ; 22 \%) ; v)$ Um novo tempo, apesar dos pesares $(N=39 ; 20 \%)$; vi) E por falar em violências $(N=35 ; 18 \%)$; vii) A violência é uma linguagem $(N=34 ; 17,4 \%)$. Três discursos do bloco de maior prevalência, intitulado "A engenharia das VPI", são apresentados integralmente neste trabalho. As narrativas das violências reveladas mostram a intensidade da vulnerabilidade e das agressões sofridas pelas mulheres e a existência de múltiplas dinâmicas violentas nos relacionamentos intimo-afetivos.

Palavras-chave Violências baseadas em gênero, Violências por parceiros intimos 


\section{Introdução}

O tema das Violências por Parceiros Íntimos (VPI), termo usado como sinônimo para violências baseadas em gênero (VBG), ainda que o último seja mais amplo, emerge no cenário contemporâneo como uma das principais expressões de violação dos direitos humanos que ocorrem no âmbito das relações interpessoais. Esse tema apresenta semelhança de sentido com a temática da violência contra a mulher (VCM) e da violência doméstica ( $\mathrm{VD})$, mas tem sido mais utilizado recentemente por implicar maior especificidade na descrição operacional da categoria "parceiro íntimo" como perpetuador das violências no contexto das relações íntimo-afetivas. Esta pesquisa utiliza a descrição de parceiros íntimos cunhada pela Organização Mundial de Saúde (OMS) no seu estudo multipaíses sobre violência e saúde da mulher ${ }^{1}$.

A complexidade da temática das VPI exige considerar as condições estruturantes do tecido social brasileiro e da violência social, que se tornou uma questão pública tingida pelas desigualdades sociais; exige, ao mesmo tempo, validar o enfoque no caldo cultural (re)produzido pelo sistema patriarcal, que é conhecido por gerar assimetria de poder nas interações humanas. O legado do patriarcado privilegia a dominação pelo gênero masculino e fertiliza as condições para o acirramento das violações de direitos humanos. O termo VBG descreve as questões ligadas a gênero - construção social das identidades femininas e masculinas -, as relações assimétricas geradas pelos sistemas de opressão - gênero, classe social, etnia -, e as formas de violências que mediam os conflitos baseados na essencialização das masculinidades ${ }^{2-4}$ e feminilidades, quer de natureza física, psicológica, sexual, patrimonial ou moral.

Além da assimetria de gênero, os acontecimentos violentos entre parceiros íntimos precisam ser analisados a partir de um olhar que procure perceber o impacto das estruturas sociais e das interações nos espaços micro e macro onde os relacionamentos interpessoais ocorrem, bem como o impacto da modernidade nas múltiplas dimensões da condição humana ${ }^{5-7}$. $\mathrm{Na}$ área da saúde, as violências praticadas por parceiro íntimo geram consequências prolongadas e susceptibilidade a uma grande diversidade de doenças, configurando-se globalmente como um dos mais graves problemas sociais que afetam a saúde de grupos populacionais específicos, por exemplo, as mulheres ${ }^{8,9}$. No Brasil, o processo de inclusão da violência na agenda da saúde tem sido marcado por inúmeras dificuldades, mas importantes avanços têm sido garantidos, conforme descreve Minayo $^{10}$.

Esta pesquisa teve como objetivo conhecer os discursos de mulheres de 15 a 49 anos moradoras do Varjão sobre suas vivências, bem como algumas representações de gênero e violência expressas nesses discursos. As narrativas dos episódios de violências praticadas por parceiros íntimos descrevem um fenômeno multidimensional ancorado na interface entre indivíduos e sociedade.

\section{Delineamento do corpo, construção do corpus}

Assumiu-se que a violência é um problema complexo enraizado na interação de fatores biológicos, sociais, culturais, políticos e ambientais. Além disso, considerou-se gênero como um conceito que auxilia na explicação dos comportamentos violentos dos parceiros íntimos. As construções culturais e sociais de o que significa ser homem e ser mulher orientam as relações estabelecidas pelos indivíduos com a família, com pessoas conhecidas e desconhecidas na comunidade e com outros grupos sociais. Entretanto, nem a cultura é estática, nem a história é apenas uma reprodução ou memória do passado. A violência é um significante e as mulheres entrevistadas constroem significados que podem estar manifestos nas suas narrativas.

Uma narrativa veicula e comunica uma fala, obedecendo a uma estrutura que atribui sentido às experiências humanas, à lógica e à racionalidade dos relacionamentos, transcendendo a gramaticalidade própria de uma língua. Nesse sentido, narrativas são práticas sociais desenvolvidas num tempo e num contexto historicamente delimitado. Elas representam uma aproximação do real e do simbólico dos discursos elaborados no coletivo e expressos pelos indivíduos. Práticas discursivas marcam posicionamentos e podem tanto reproduzir identidades tradicionais como construir identidades em movimento. Assim, narrativas são construções linguísticas da realidade socialmente criada cujos significados se encontram para além da linguagem. Os indivíduos exercitam suas memórias e registram suas falas narrando histórias de luta e sobrevivência, ao mesmo tempo em que descrevem elementos do caráter coletivo do pensamento social. Narrativas de violências vividas no mundo concreto expressam formas do pensamento e da cognição das sobreviventes das VPI. 
Para Foucault, o discurso é a tentativa de usar a linguagem para comunicar uma ideologia, constituindo-se, por isso, numa prática social. Discursos, portanto, são visões de mundo identificáveis não isoladamente, mas sim em conexão com acontecimentos, ideias e vozes de outros sujeitos que antecederam sua enunciação. $\mathrm{O}$ autor afirma:

"Nisto não há nada de espantoso, visto que o discurso - como a psicanálise nos mostrou não é simplesmente aquilo que manifesta (ou oculta) o desejo; é, também aquilo que é o objeto do desejo; e visto que - isto a história não cessa de nos ensinar - o discurso não é simplesmente aquilo que traduz as lutas ou os sistemas de dominação, mas aquilo por que, pelo que se luta, o poder do qual nos queremos apoderar"11.

Nas relações cotidianas entre parceiros íntimos, a presença de autoritarismo e de violência gera uma linguagem de agressividade que transcende o casal e atinge outros possíveis atores, como crianças, adolescentes, jovens e idosos que convivem no mesmo espaço que a mulher agredida. Essa linguagem organiza as interações e afeta a dinâmica familiar, tecendo um cenário de tensões, agressões e novos medos, num ciclo que tende ao escalonamento e não à redução. Narrativas acerca dessa linguagem violenta podem ajudar a perceber matizes e nuances da interação mediada pelo uso da violência e revelar fontes de representações sociais acerca do que as mulheres pensam sobre o fenômeno.

Nesta pesquisa, as causas associadas ao fenômeno da violência praticada contra a mulher pelo parceiro íntimo foram pensadas como um coletivo de determinantes. O estudo parte do pressuposto teórico de que nenhum fator isolado explica por que uma pessoa sofre e/ou pratica violência. Apesar disso, acredita-se ser possível identificar algumas camadas, tanto no plano individual como no coletivo, nas quais a violência se inscreve. As narrativas descrevem alguns dos sentidos evidenciados nos discursos das entrevistadas e descortinam algumas camadas da realidade percebida e vivida no cotidiano das interações íntimo-afetivas.

\section{Método}

Neste estudo, de caráter qualitativo, mulheres entre 15 e 49 anos moradoras da região metropolitana de Brasília narraram suas experiências diretas ou indiretas com múltiplas manifestações de violência. A amostra foi de conveniência e um total de 195 mulheres escolheu narrar suas histórias de violência.

As falas das entrevistadas corporificaram as narrativas particulares de mulheres sobreviventes da VPI e ao mesmo tempo expressaram os signos e as representações sociais por elas apreendidas. Os discursos eram semelhantes em temática, ainda que cada experiência tenha sido vivenciada por indivíduos diferentes e de maneiras diversas. Tais vivências se transformam em ícones coletivos do pensamento de pessoas que dividem uma estrutura simbólica semelhante, individualizando um sentido numa soma qualitativa e gerando um discurso coletivo. Lefevre e Lefèvre afirmam:

"Se na escala individual, pensar, opinar implica, natural e espontaneamente, discursar, ou seja, posicionar-se enunciando opiniões, argumentos, justificativas, o mesmo deveria acontecer na escala coletiva, o que de fato acontece no DSC, no qual um sujeito coletivo reconstruído, falando na primeira pessoa do singular, mas expressando o pensamento semelhante de diferentes sujeitos individuais, mimetiza, iconicamente, na escala coletiva, o pensamento emitido na escala individual" 12 .

O estudo utilizou o Discurso do Sujeito Coletivo (DSC) $)^{13,14}$. O DSC é uma técnica da pesquisa social crítica que se presta a organizar os conteúdos das falas das pessoas entrevistadas por intermédio de um instrumento de coleta de dados formulado com sistema aberto de resposta. Entretanto, a técnica representa muito mais do que uma metodologia de organização de respostas. O DSC se preocupa em permitir a discursividade dos processos mentais de uma coletividade - as representações sociais presentes no pensamento coletivo - por meio de discursos-sínteses de sentidos semelhantes emitidos pelas pessoas. Ele é composto por quatro operações:

a) expressões-chaves: descrição dos temas principais do discurso e apresentação das transcrições integrais de partes do depoimento;

b) ideias centrais: síntese descritiva dos conteúdos enunciados nas expressões-chaves;

c) ancoragens: representações sociais que foram explicitamente narradas nas expressões-chaves. As ancoragens podem ou não estar presentes nas expressões-chaves;

d) Discurso do Sujeito Coletivo (DSC): conjunto das expressões-chaves organizadas segundo ideias centrais de significados semelhantes. Trata-se de um discurso-síntese feito na primeira pessoa do singular.

A importância do uso dessa técnica nos estudos sobre violência reside também no fato de 
que a violência é uma forma de comunicação, uma linguagem que descreve padrões de interação social, justificando a escolha de que o DSC narre a fala inserida nessa linguagem. Os discursos das violências sofridas possuem qualidades que diferenciam as experiências vividas pelas mulheres. Essas qualidades de ideias centrais não apenas demonstram o mosaico que compõe as experiências com VPI como também anunciam e denunciam a intensidade das dores e traumas sofridos pelos indivíduos e pelo "eu coletivo" ou o coletivo inconsciente, que fala por intermédio do indivíduo. Assim, o DSC permite obter o pensamento coletivo indutivamente, preservando sua natureza discursiva. A coletividade se torna sujeito do discurso de forma icônica, ou seja, o DSC expressa a opinião que a coletividade discursa por intermédio dos indivíduos.

Na pesquisa, após a aplicação de um instrumento de coleta de dados desenvolvido pela OMS para estudos envolvendo violência contra a mulher, a entrevistadora apresentava a descrição das violências segundo a natureza psicológica, física e sexual dos atos cometidos pelos parceiros ${ }^{1}$. Em seguida, era feita uma pergunta do tipo sistema aberto de resposta, que desencadeava as narrativas de violências. A pergunta era: "Caso você tenha sofrido algum tipo de violência, você gostaria de narrar algum episódio? Gostaria de falar sobre o que ocorreu?". A questão, aberta e não diretiva, visava obter da entrevistada-sujeito o que ela considerava mais relevante para ser narrado livremente, o que podia corresponder a suas experiências, situações descritas pela entrevistada como violência, comportamentos violentos praticados por ela e contra ela, e opiniões, atitudes e/ou percepções acerca da violência. A oportunidade de fala, para muitas das mulheres entrevistadas, possibilitou que elas "nomeassem o abuso, interpretassem o abuso como opressão, re-experimentassem o sentimento de raiva com o ocorrido e realizassem a transição de vítima para sobrevivente" 15 .

As narrativas eram registradas manualmente e transcritas em um processador de texto. A entrada dos dados era feita com frequência semanal ou quinzenal. Quanto aos procedimentos técnicos para a organização das narrativas das mulheres, as etapas adotadas foram:

. Fizeram-se leituras sucessivas das narrativas registradas usando literalmente as palavras faladas. No geral foram falas curtas, uma vez que muito tempo já havia sido investido no decorrer das demais partes da entrevista. Nesse momento final da entrevista, 195 mulheres optaram por descrever algum fato ou acontecimento violento da sua trajetória de vida. O recurso de gravação digital não foi utilizado, pois os parceiros das entrevistadas podiam chegar a qualquer momento, e optou-se por reduzir o risco de exposição das entrevistadas às suspeitas dos parceiros.

- Organizaram-se os discursos obedecendo ao seguinte padrão: com os discursos já digitados, selecionavam-se, por meio de uma nova leitura, quais eram as ideias centrais provisórias e suas respectivas expressões-chaves em cada uma das 195 respostas à pergunta aberta. Adotou-se um esquema de marcação com cores diferentes para delimitar as ideias centrais e as expressõeschaves.

- Após essa etapa, as ideias centrais provisórias eram agrupadas em torno de uma mesma temática e dispostas segundo grandes temas divididos por ordem alfabética.

. Em seguida, realizaram-se novas leituras para confirmação das ideias centrais permanentes. Caso houvesse representações sociais claramente ancoradas no texto, elas também eram marcadas separadamente.

- A relação das ideias centrais foi reavaliada e aquelas que apresentavam semelhança de sentido eram agrupadas a fim de evitar redundâncias.

. Expressões-chaves agrupadas por letras semelhantes, ou seja, pertencentes à mesma categoria de ideias, eram colocadas num quadro chamado DSC I, que constava de duas colunas: na esquerda, as expressões-chaves semelhantes, e na direita, o ordenamento de um discurso como se houvesse um indivíduo falando na primeira pessoa do singular, mas que ao mesmo tempo representasse uma coletividade, pois era composto por muitas vozes.

. Finalmente, o discurso-síntese (DSC II), com os sujeitos-coletividade "discursando" seus pensamentos sobre as mais diversas manifestações violentas que os impactaram.

. Por questão de segurança, os questionários foram devidamente protegidos e selados para garantir a confidencialidade das informações colhidas.

Atendendo aos pressupostos éticos e de acordo com a Resolução 196/96, do Conselho Nacional de Saúde, toda a informação coletada nas entrevistas teve a garantia de confidencialidade de modo a não permitir a identificação e garantir a segurança das pessoas envolvidas na pesquisa. O estudo foi submetido à Comissão de Pesquisa e Ética da Faculdade de Saúde da Universidade de Brasília para parecer e aprovação, e apenas depois desta as entrevistas foram iniciadas. 


\section{Resultados}

No tocante às características sociodemográficas, $45 \%$ das mulheres entrevistadas tinham entre 25 e 34 anos, $62 \%$ possuíam apenas ensino fundamental incompleto e $58 \%$ declararam estar desempregadas ou à procura de emprego. Quanto aos parceiros, a idade mediana foi de 32 anos e a precariedade da escolaridade foi ainda maior, com $71 \%$ deles apresentando apenas ensino fundamental incompleto. Em relação ao consumo de bebida alcoólica, 12\% das mulheres afirmaram que seus parceiros faziam uso todos os dias ou quase todos os dias, e $49 \%$ delas relataram que o parceiro bebia moderadamente (duas ou três vezes por semana).

Com relação às múltiplas violências no cotidiano, as 195 narrativas continham fragmentos de experiências de diferentes espécies de violência. As narrativas são estruturadas mediante o discurso da entrevistada-sujeito que esteve envolvida nos acontecimentos narrados e construiu uma realidade sobre o fato. O discurso dessa realidade conta histórias vividas em contextos particulares pelas sobreviventes ou pelas testemunhas das violências. Nesta seção, dos resultados, apresentamos o discurso da realidade e, na seção de discussão, trataremos do discurso sobre a realidade, conforme sugere Lefevre e Lefevre ${ }^{14}$.

Nesta pesquisa, o DSC possibilitou aos sujeitos narrarem suas vivências de violência e seus movimentos históricos de resistência e submissão. Ao mesmo tempo, a técnica permitiu "escutar" uma voz que antecede esse discurso e que impregna o cotidiano do falante a ponto de se tornar parte constitutiva de sua fala. A essa voz, dá-se o nome de coletividade. As práticas discursivas e os poderes que as interpenetram também são manifestos no discurso. Essas práticas possuem enunciados produzidos por diferentes vozes e com distintos conteúdos. Elas são dinâmicas e se constituem em referências que funcionam como um repertório de representações para o sujeito trabalhar com a construção de sentido para situações cotidianas. Esse repertório constitui-se no foco da Teoria das Representações Sociais ${ }^{16,17}$.

A análise das 195 narrativas apresentou 397 ideias centrais que resumiram a essência das expressões-chaves presentes nas falas das mulheres. Essas 397 expressões-chaves e ideias centrais foram agrupadas por semelhança ou complementaridade de sentido e formaram 32 Discursos do Sujeito Coletivo. Esses DSC descreveram um mosaico de múltiplas vivências de violências que o levantamento de dados estatísticos detec- tou por intermédio do instrumento da OMS. Entretanto, os DSC revelaram matizes e nuances das violências que não faziam parte da investigação feita por intermédio das questões de sistema fechado do instrumento utilizado (Tabela 1).

Os 32 DSC foram agrupados em sete blocos temáticos: Engenharia das violências praticadas por parceiros íntimos (8 DSC), Histórias de estupro de vulneráveis (6 DSC), Violências silenciosas ou silenciadas (4 DSC), Anos potenciais de vida sofrida (4 DSC), Um novo tempo... apesar dos pesares (4 DSC), E por falar em violência (2 DSC) e A violência é uma linguagem (4 DSC). A Tabela 1 ilustra a proporção dos DSC segundo blocos temáticos.

Na sequência, serão apresentados três discursos dos sujeitos desta pesquisa, bem como as teias discursivas que compõem as múltiplas violências baseadas em gênero e o cruzamento do indivíduo com o social.

\section{Discurso do Sujeito Coletivo 1}

\section{Ideia central: Uso de bebidas alcoólicas e drogas relacionados à VPI}

\section{Coquetel violento}

Meu pai bebe muito e algumas vezes ele briga com minha mãe e bate nela. Fala que vai matar ela, mas são só palavras. Não faz nada mais do que bater. Minha mãe apanhou muito de meu pai quando ele chegava bêbado. Meu pai era alcoólatra e quando bebia ele batia muito nela. Além disso, meu padrasto bebe e ele fica xingando minha mãe e tenta bater nela, mas ela não deixa. Meu padrasto bebia muito e batia nela. Uma vez ele pegou um facão e bateu nas costas dela e ficou uma marca roxa.

Meu pai bebia muito e batia muito na minha mãe. Depois de uns oito anos, ele adoeceu com um problema do fígado e aí ele voltou para a igreja e parou de bater na minha mãe.

Ano passado o marido da minha irmã bateu nela. Ela não quis denunciar e começou a beber. Hoje, ela bebe muito e é ela que bate nele e ele só se defende e não bate nela.

Meu primeiro marido bebia demais e ficava agressivo e me batia muito. Tinha alguém sempre para me salvar. Ele bebia demais e dormia com a faca debaixo do travesseiro. No começo ele não me agredia. Ele saía direto para os bares e festas e com o tempo ele começou a chegar bêbado. Ele começou a pegar o facão e bater em minhas costas... Surra de facão. Um dia meu filho ouviu no bar que ele ia me matar naquela noite. Uma vez ele estava bêbado e 
Tabela 1. Proporção dos Discursos do Sujeito Coletivo segundo Ideias Centrais de sentidos semelhantes. Varjão, DF, 2007

\begin{tabular}{|c|c|c|}
\hline DSC Sínteses(Agrupados por Semelhança temática) & $\begin{array}{c}\text { Número de EC } \\
\text { e/ou IC }\end{array}$ & $\%$ \\
\hline 1. Engenharia das VPI - 8 Discursos & 114 & 58.5 \\
\hline Coquetel Violento & 28 & 14.4 \\
\hline Adeus "Lua de Mel", só sobrou tensão e agressão & 21 & 10.8 \\
\hline Na companhia do medo: mulheres em estado de alerta e temor constante & 19 & 9.7 \\
\hline Gravidez de risco... violência como diagnóstico & 16 & 8.2 \\
\hline Histórias de traição e violência & 12 & 6.2 \\
\hline Coerção sexual ou estupro? & 9 & 4.6 \\
\hline Naturalização da violência & 5 & 2.6 \\
\hline Quando o medo fala mais alto & 4 & 2.1 \\
\hline 2. Histórias de estupro de vulneráveis - 6 Discursos & 77 & 39.5 \\
\hline Nossa ele era família! & 30 & 15.4 \\
\hline Foi aí que entendi o que ele fez comigo & 22 & 11.3 \\
\hline Silêncio dos inocentes & 12 & 6.2 \\
\hline Memórias que machucam & 5 & 2.6 \\
\hline Casamento ou estupro de vulneráveis? & 4 & 2.1 \\
\hline O perigo na rua & 3 & 1.6 \\
\hline 3. Violência Silenciosa ou Silenciada? - 4 Discursos & 43 & 22.1 \\
\hline Em briga de marido e mulher a família não está metendo a colher & 16 & 8.2 \\
\hline Tendo os filhos por testemunhas & 12 & 6.2 \\
\hline Quando a criança fala e o cuidador cala & 10 & 5.1 \\
\hline Nem você fala e nem eu pergunto & 5 & 2.6 \\
\hline 4. Anos potenciais de vida sofrida -4 Discursos & 43 & 22.1 \\
\hline Tudo começou muito cedo & 20 & 10.3 \\
\hline Minha vida toda eu fui um saco de pancada & 11 & 5.6 \\
\hline Entre o ficar e o partir & 7 & 3.6 \\
\hline Pensando na saída & 5 & 2.6 \\
\hline 5. Um novo tempo... apesar dos pesares - 4 Discursos & 39 & 20.0 \\
\hline Hoje é tempo de empoderamento & 21 & 10.8 \\
\hline Maria da Penha neles... & 9 & 4.6 \\
\hline Narrar ajuda a curar & 6 & 3.1 \\
\hline Tô feliz com meu parceiro & 3 & 1.6 \\
\hline 6. E por falar em violência - 2 Discursos & 35 & 18.0 \\
\hline Varjão: O crime nosso de cada dia & 28 & 14.4 \\
\hline Violências e mais violências & 7 & 3.6 \\
\hline 7. Violência é uma linguagem - 4 Discursos & 34 & 17.4 \\
\hline A linguagem da retribuição & 13 & 6.7 \\
\hline O descontrole do controle & 9 & 4.6 \\
\hline O discurso religioso & 8 & 4.1 \\
\hline Fui eu que comecei & 4 & 2.1 \\
\hline
\end{tabular}

atirou em mim (...). Mas errou o tiro e meu irmão chegou e conseguiu tirar o revólver dele. Larguei dele depois disso. Ele já me humilhou muitas vezes. E me bateu uma vez. No natal ele chegou bêbado em casa e me bateu. Eu fui para a casa da minha tia e fiquei lá até ele se acalmar. (...) Ele começou a vender e usar drogas e ficou violento. Me bateu algumas vezes e me ameaçou com arma uma vez. Mas ele era um bom homem. As vezes que eu apanhei do meu marido foi porque ele chegou bêbado e eu fui reclamar e ele me socou. Meu marido já me empurrou e me deu tapas muitas vezes. Quando ele fica bêbado, ele pega a faca e fica batendo nos móveis até lá fora da rua e fica como um louco dizendo que vai matar todos nós. Sempre que ele bebia dava soco ou tapa.

$\mathrm{Na}$ verdade, toda vez que ele bebia, ele ficava violento. O problema é que ele bebia quase todo dia. Ele me ameaçava que se eu chamasse a polícia para ele, ele ia me matar. Numa vez que ele estava 
bêbado, ele chegou em casa brigando e derrubando minhas comidas. Um dia o pai da minha filha chegou bêbado e rasgou a minha calcinha. Eu acho que porque meu marido bebia muito, quando ele chegava em casa ele me batia. Ele usava drogas e roubava. Ele bebia muito (...). Ele foi embora e eu fiquei com as crianças. O meu marido atual também bebe e quando chega aqui em casa grita comigo e me humilha. Queria que ele mudasse.

Já meu ex-marido me acordava com um revólver na cabeça, com faca, com machado ou qualquer outra coisa. Isso acontecia quando ele chegava em casa bêbado e eu já estava dormindo. Uma noite meu ex-marido chegou bêbado em casa e começou a me xingar, me chamando de vagabunda pois um outro bêbado tinha dito que eu tinha um amante. Eu estava dormindo com meus filhos em casa e ele começou a brigar e me apertou o pescoço que eu fiquei sem ar. Na última vez que ele me bateu, eu peguei ele e empurrei na parede. Ele estava bêbado. Além disso, ele usava maconha e cocaína. (...) Ele me batia, colocava o revólver na minha cabeça quando eu não deixava usar minha casa como ponto de venda da droga. Sempre que ele bebia dava soco ou tapa. Ele mexe com droga. Ele é muito perigoso.

\section{Discurso do Sujeito Coletivo 2}

\section{Ideia central: Tensão e agressão: o ciclo da violência perde a fase da "lua de mel"}

\section{Adeus, "Lua de mel"}

Já apanhei demais. Muitas e muitas vezes. Ele nem prometia mais que não ia mais bater. Meu marido quase me matou. Um dia eu fui para o Hospital de Base desmaiada. No começo ele prometia que ia parar de bater, mas depois ele batia e nem falava nada. Levei tanta surra. Ele vive falando que vai me mandar num pacotinho para o Piauí e vai me cortar em pedacinhos e me mandar de volta para lá. Ele põe a faca no meu pescoço e muitas vezes ele tentou me enforcar com as mãos. Uma vez ele começou a gritar e pegou uma faca na gaveta. "Vou te furar para ficar livre de você." Eu lutei com ele e segurei a faca e cortei a minha mão. E aí começava a porrada. Ele batia, chutava, socava e apertava meu pescoço muitas vezes.

Já apanhei muito (...). Era medo e surra todo tempo. Uma das vezes que ele me espancou, ele me machucou tanto (...), eu perdi a visão do olho esquerdo. Esse meu marido era um monstro comigo. Chegava em casa atirando. Ele bebia muito. Um dia ele me bateu com fio de luz que eu não conse- guia vestir roupa. Meu corpo ficou todo cortado. Ele botava revólver na minha cabeça e me fazia transar com ele. Isso durou muito tempo. Eu vivia esperando a próxima pancadaria.

Sabe, eu trazia o dinheiro para casa e ainda levava. Uma vez ele jogou um prato de comida quente em cima de mim e me queimou. Às vezes quando eu estava cansada e dormia e me esquecia de virar ele na cama - por causa da paralisia - ele me acordava com um murro e me batia muito. Ele nem pedia perdão ou prometia qualquer coisa. Eu fugi com as crianças para Minas Gerais, mas ele foi atrás de mim e eu voltei e tudo continuou igual como antes. Ele nem prometia mais não bater em mim.

Já o meu primeiro companheiro me furou com um punhal nas costas (olha aqui as cicatriz). Um dia, ele me deu uma enxadada na cabeça, eu desmaiei (...). Logo depois ele espancou de novo e tocou fogo no barraco que a gente morava. Não acho que ele vai parar de me bater. Não espero mais isso. Ele bate e depois passa um tempo, volta a bater de novo. Assim, desse jeito... Um dia, ele chegou me batendo dizendo que eu tinha outro, apertou meu pescoço e jogou uma panela em mim. Eu gritei por socorro e a vizinha avisou que ia chamar a polícia e ele escapou. Ele chegou me espancando, puxando meus cabelos, me arrastou no asfalto, me deu chute no peito e eu desmaiei.

Meu marido me batia de murro, jogava pau em cima de mim, corria atrás de mim com machadinha, chave de fenda e martelo, faca e formão. A machadinha ele pôs no meu pescoço para me cortar. Ia descer a machadinha no meu pescoço para me cortar, mas eu gritei e o sobrinho dele chegou e tomou dele. Depois de nove anos aguentando tudo isso sem nunca melhorar eu larguei dele.

Ele me batia demais, me humilhava, me ofendia, me xingava, ameaçava e tentou muitas vezes usar arma e faca em mim. Ele já nem prometia melhorar. Eu vivia esperando a pancadaria. No final ele já não prometia nada de parar de bater. Era só bater e esperar para a próxima.

\section{Discurso do Sujeito Coletivo 3}

\section{Ideia central: Mulheres em estado de alerta e temor constante}

\section{Vivendo na companhia do medo}

Eu vivi a minha vida de casada toda cheia de medo. Só no olhar, ele me controlava e eu obedecia. Ele me controlava em silêncio. (...) Ele me dava tanto medo que eu não dormia a noite. Eu quero separar dele e ele não aceita a separação. Eu tenho 
medo, pois ele me ameaça que eu não vou ter paz se separar dele. O irmão do meu marido matou uma mulher aqui no Varjão. Eu tenho muito medo do meu marido fazer o mesmo comigo. Eu vivo ameaçada vinte e quatro horas por dia. Tudo do meu companheiro é me matar. Eu tenho muito medo e não faço nada.

Quando ele começava a brigar eu ficava morrendo de medo dele me matar. Ele já me ameaçou e me deu medo muitas vezes. Quando começa a discussão eu fico calada porque tenho medo dele. Várias vezes eu ia à defensoria pública, pois eu morria de medo porque ele me ameaçava demais.

Hoje estamos separados, mas tenho ainda muito medo dele. Não posso namorar, pois tenho medo pela minha vida. Ele tem várias namoradas e eu não posso ter nenhum. Eu larguei dele, mas até hoje ele me ameaça. Ele anda armado. Ele é muito perigoso. (...) Ele está solto porque eu arquivei o processo por medo dele. (...) No dia seguinte, ele voltou a morar aqui e hoje ele não bate, mas me ameaça o tempo todo. A primeira mulher dele foi morta por ele. Só ficou preso por seis meses, pois eles conseguiram provar que ele só estava limpando o revólver quando a arma disparou. Uma vez, meu primo o ameaçou de morte. Só que meu primo morreu e hoje meu ex-marido voltou a morar aqui no Varjão e eu vivo com medo dele. Já fui ameaçada muitas vezes e ele fazia muitas vezes coisas que me davam medo. Uma vez ele tentou me estrangular.

Eu estou conversando aqui com você, mas tenho que ficar vigiando para ver se ele não vai chegar antes da hora. Olha só os papéis da vez que eu chamei a polícia para ele. E esse é da delegacia da mulher... Nunca dá em nada. Eu fico com medo de ir em frente.

Então é isso, eu vivo com medo dele. Ele vive me ameaçando. Eu vivo esperando a próxima pancadaria.

Ele vive me ameaçando. Eu vivo esperando a próxima pancadaria.

Depois de 10 anos, contadinhos, eu consegui largar dele. Quando a gente é muito ameaçada a gente aguenta ficar pelo medo. Hoje, ele não me bate, mas tem muitas vezes que eu tenho medo dele (...). Ele não me bate, mas eu vivo sempre com medo.

\section{Discussão}

Aprofundar-se na temática das violências interpessoais implica descobrir que a VPI é um fenômeno em movimento. Além disso, discorrer so- bre os discursos narrativos das violências exige uma constante submissão ao fato de que gênero é um fenômeno relacional. Os pesquisadores precisam estar prontos para questionar seus próprios pressupostos e tomar o cuidado de apresentar as conclusões como algo fluido e dinâmico conectado com dimensões de micro e macroambientes.

A engenharia das violências praticadas por parceiros íntimos, o bloco com o maior número de expressões-chaves e DSC, descreve os mecanismos, as cenas e os cenários das VPI. No primeiro DSC, encontra-se o imaginário acerca do coquetel perigoso que álcool-droga e violência apresentam. As representações sociais da entrevistada de que o álcool é causa das agressões aparecem em várias expressões-chaves. Parece passar despercebido para essas mulheres que o álcool não é o responsável pela agressão. Trata-se de uma substância que reduz as inibições e favorece tanto as representações que o parceiro construiu, ao longo de sua trajetória de vida, do direito sobre um corpo que não é dele, o corpo feminino, como a racionalização do uso de técnicas violentas para que esse corpo se torne "disciplinado" e obediente.

A ligação do álcool com a violência é, portanto, indireta. Os estudos confirmam que ele pode aumentar a irritabilidade, reduzir o autocontrole e a capacidade cognitiva. Mas as representações presentes no coletivo parecem influenciar homens e mulheres e corroborar com a ideia de que o álcool é a substância responsável pela violência. Assim, teríamos uma retroalimentação do sistema unidirecional álcool-violência, e as representações do uso dessa substância depressora permaneceriam no imaginário social como apresentando associação causal com os episódios violentos.

Ainda dentro da engenharia das violências, identifica-se um novo ciclo da violência. De acordo com a autora da teoria do ciclo da violên cia ${ }^{18}$, existem três fases, denominadas de tensão, agressão e lua de mel. A frequência e a duração de cada uma das fases dependem das dinâmicas das múltiplas conjugalidades e dos contextos ambientais. No caso do Varjão, não foi detectada a fase da lua de mel. As mulheres sofrem os episódios de agressão e continuam a ser ameaçadas, sem o período de pausa. O segundo DSC expressa bem a ausência de qualquer promessa de abandono do comportamento violento por parte do parceiro. Pelo contrário, observam-se momentos de descontinuidade seguidos de intensificação da gravidade dos atos violentos.

É possível perceber tonalidades de desesperança no discurso das mulheres, uma carência de 
sentido para a existência, uma ausência de projeto. É como se a ausência das pausas produzidas pelos períodos de lua de mel contribuísse para um distanciamento psíquico-emocional, como se a presença das promessas pudesse trazer alguma esperança de ruptura de um padrão cotidiano de intimidade marcada por práticas violentas. A expectativa de uma promessa parece funcionar como um mecanismo de proteção contra as profundas violações da dignidade humana.

O terceiro DSC, que enfoca a percepção de um clima de terror constante, apresenta uma mulher que vive na companhia do medo e da tensão. $\mathrm{O}$ continuum da violência fica claro no discurso das mulheres. Mesmo na ausência da continuidade da relação formal com o parceiro, o temor persiste, e um sentimento de vigilância e cautela acompanha essas mulheres. Simbolicamente o parceiro continua presente, e sua ausência física não ameniza a sensação de monitoração constante. Em outras palavras, essa situação remete a uma versão do Panóptico descrito por Foucault ${ }^{19}$, onde as mulheres vivem dentro de relacionamentos-prisões construídos pelas relações assimétricas de gênero e pelo poder disciplinador dos parceiros. A "torre de controle" não se desmancha com o término da relação íntimoafetiva, mas pode prevalecer por vários anos por intermédio de uma vigilância coercitiva dos exparceiros e pela presença de uma linguagem violenta num cenário de tensões e agressões ${ }^{20}$.

A técnica de tratamento das narrativas com o uso do DSC permitiu conservar a integridade das experiências vivenciadas pelas mulheres sobreviventes da violência praticada por parceiros íntimos. Ao mesmo tempo, conduzir pessoalmente as 300 entrevistas - num total de mais de 450 horas de escuta ativa, juntamente com pausas para a espera do momento mais oportuno e seguro para prosseguir as entrevistas - nos auxiliou no processo de ler e reler as narrativas de violência.

Durante o tratamento dos dados, alguns aspectos que estão para além das coisas ditas pelas mulheres - uma combinação entre o olhar, a escuta e a palavra - eram relembrados, permitindo que a entrevistadora revivesse muitos momentos dos diálogos. As vozes de sofrimento, indignação e profunda violação da condição humana não se calaram ao término do período da coleta de dados. Houve também vozes que expressaram libertação da opressão e estavam tingidas pela esperança de um novo tempo. As palavras ouvidas trazem retratos da verdade que foram atravessados pela tentativa da analista de não interferir na enunciação das entrevistadas. Os discursos representam uma importante ferramenta de investigação e descrevem os "jogos de força e poder" envolvidos nas relações íntimo-afetivas ${ }^{21}$.

Pensamos ser relevante registrar algumas considerações referentes às altas prevalências de abusos sexuais e violências múltiplas nas narrativas registradas neste estudo. Em primeiro lugar, gostaríamos de ressaltar que alguns aspectos metodológicos podem ter contribuído para aumentar a revelação da ocorrência de violências, em especial as de natureza íntimo-afetiva, as quais têm sido descritas como mais difíceis de desvelar do que outras violências interpessoais. A técnica utilizada na entrevista incluiu momentos de silêncio e pausas, respeitando o ritmo individual da mulher. Todas as entrevistas foram conduzidas pela coordenadora da pesquisa, permitindo maior homogeneidade nas estratégias para deixar as entrevistadas em situação confortável e favorável à revelação de episódios dolorosos que, em muitas ocasiões, estavam sendo narrados pela primeira vez. A necessidade de pessoas com experiência na área das violências interpessoais representa um desafio no preparo logístico de estudos de base populacional envolvendo múltiplos entrevistadores.

Ao longo das entrevistas, houve momentos reais de confronto com uma violência "no ar", uma exposição direta a ambientes violentos, um compromisso ético com a segurança e a integridade emocional das entrevistadas. O método, a técnica e a ética não se separaram em momento algum, mesmo que isso tenha resultado em um gasto muito maior de tempo e energia do que tinha sido inicialmente planejado para a duração do período de entrevistas.

A conjugalidade é um espaço de conquista de direitos para expressar individualidades. Nem toda conflictualidade conjugal se caracteriza como violência. Além disso, nesta pesquisa atos importantes de violência psicológica, como calúnias, difamações e agressão patrimonial, não foram incluídos no instrumento de coleta de dados para não alterar a estabilidade do instrumento da $\mathrm{OMS}^{1}$. Outras variáveis sociodemográficas, como renda e raça/etnia (ainda que renda sirva de proxy para etnia/raça), não foram incluídas no questionário.

As histórias de violências narradas ao longo das entrevistas foram mantidas e o uso do DSC permitiu a apreciação da dimensão múltipla de violências que acontecem na trajetória de vida de grupos vulneráveis. A preocupação constante 
durante a pesquisa foi a de apreender o mundo social das mulheres participantes do estudo sem eliminar a integridade subjetiva que atribui significado aos dados coletados. O delineamento metodológico procurou evitar o absolutismo da mensuração e ressaltar a abordagem ecológica interação entre pessoa, processo, contexto e tempo - do fenômeno.

O que se registra aqui é fruto de uma elaboração acadêmica que se presta também a representar o papel de um memorial, com a intenção pessoal e política de agendar as violações dos direitos humanos das mulheres moradoras do Varjão na pauta das prioridades dos sujeitoscidadãos, da comunidade e do Estado. Portanto, o trabalho possui dimensões que transcendem um relato acadêmico e tem cumprido outras funções sociais junto à população pesquisada. Por exemplo, a dimensão ecológica das manifestações das violências foi abordada em forma de um programa de treinamento de liderança com o propósito de capacitar pelo menos uma mulher residente em cada quadra do Varjão acerca da dinâmica das violências e da necessidade do empoderamento individual, familiar, comunitário e societário.

Entre as limitações do estudo está a não inclusão tanto de mulheres com mais de 49 anos quanto da população masculina. Em razão do aspecto relacional do conceito de gênero, o estudo se beneficiaria da inclusão das narrativas dos parceiros acerca das violências praticadas e sofridas nas suas relações íntimo-afetivas. Assim, o fato de o parceiro não ter sido ouvido, de suas percepções e narrativas não terem sido analisadas, limita a descrição do fenômeno. No entanto, é importante ressaltar que a não inclusão des- ses parceiros foi uma decisão projetada. Sendo o Varjão um espaço urbano pequeno, é bem possível que a realização das entrevistas com os parceiros pudesse colocar as mulheres entrevistadas em situação de risco. A pesquisa, ao optar por não abranger as narrativas dos homens, termina por não contemplar o aspecto relacional do conceito de gênero, mas os riscos envolvidos e o compromisso ético de zelar pela segurança das mulheres impediram que o estudo incluísse entrevistas com os parceiros.

Cabe ressaltar outra limitação, que diz respeito à opção metodológica de aplicar, ao término da entrevista estruturada, apenas uma questão aberta, sem interferir no fluxo da narrativa da situação de violência escolhida pela entrevistada. Optou-se por não acrescentar outras perguntas que poderiam oferecer maiores informações sobre o fenômeno da violência revelado à entrevistadora, uma vez que já havia sido aplicadas 57 questões na parte inicial da entrevista.

Espaço social economicamente vulnerável, o Varjão encontra-se em fase de transição. Ele deixa de ser um local de passagem de migrantes provenientes de outras regiões do Brasil em busca de melhores condições de vida e passa a ser um local de permanência para muitos que ali se estabelecem. Os resultados do estudo já têm contribuído para a construção da violência contra as mulheres como problema social e possibilitado a elaboração de políticas locais para uma comunidade em fase de organização de seus conselhos e espaços de controle social. As narrativas das violências sofridas tornaram-se, assim, um desafio comunitário a reclamar iniciativas públicas e intervenções do Estado a fim de notabilizar a rede de atenção às vítimas de violência baseada em gênero.

\section{Colaboradores}

LBA Moura, F Lefevre e V Moura participaram igualmente de todas as etapas de elaboração do artigo. 


\section{Referências}

1. World Health Organization (WHO). WHO multicountry study on women's health and domestic violence against women. Geneva: WHO; 2005.

2. Connell RW. Hegemonic masculinity: rethinking the concept. Gender \& Society 2005; 19(6):829-859.

3. Peralta RL, Tuttle LA, Steele JL. At the Intersection of Interpersonal Violence, Masculinity, and Alcohol Use: The Experiences of Heterosexual Male Perpetrators of Intimate Partner Violence. Violence Against Women 2010; 16(4):387-409.

4. Batista LE. Masculinidade, raça/cor e saúde. Cien Saude Colet 2005; 10(1):71-80.

5. Bauman Z. Vidas desperdiçadas. Rio de Janeiro: Zahar; 2005.

6. Bauman Z. Vida líquida. 2a Ed. Rio de Janeiro: Zahar; 2009.

7. Bauman Z. Vidas em fragmentos. Rio de Janeiro: Zahar; 2011.

8. Ellsberg M, Jansen HA, Heise L, Watts CH, GarciaMoreno C. Intimate partner violence and women's physical and mental health in the WHO Multi-Country Study on Women's Health and Domestic Violence: an observational study. Lancet 2008; 371(9619): 1165-1172.

9. Bailey BA. Partner violence during pregnancy: prevalence, effects, screening, and management. International journal of women's health 2010; 2(1):183-197

10. Minayo M. The inclusion of violence in the health agenda: historical trajectory. Cien Saude Colet. 2006; 11(2):375-383.

11. Foucault M. A ordem do discurso. $18^{\text {a }}$ Ed. São Paulo: Loyola; 2009.

12. Lefévre F, Lefréve AMC. Pesquisa de representação social: um enfoque qualiquantitativo. São Paulo: Liberlivro; 2011.

13. Lefévre F, Lefréve AMC. O sujeito coletivo que fala. Interface Comum Saúde Colet 2006; 10(20):517-524.
14. Lefévre F, Lefréve AMC. Depoimentos e discursos: uma proposta de análise em pesquisa social. Brasília: Líber Livro Editora; 2005.

15. Riger S, Raja S, Camacho J. The radiating impact of intimate partner violence. J Interpers Violence 2002; 17(2):184-205.

16. Moscovici S. Representações sociais: investigações em psicologia social. 5a Edição. Petrópolis: Vozes; 2007.

17. Jodelet D. Representações sociais: um domínio em expansão. In: Jodelet $\mathrm{D}$, organizadora. As representações sociais. Rio de Janeiro: Ed UERJ; 2001. p. 1744.

18. Walker L. The battered women syndrome. New York: Springer Publishing Co.Inc; 2000.

19. Foucault M. Vigiar e punir: nascimento da prisão. 36 Ed. Petrópolis: Vozes; 2007.

20. Moura LBA, Moura B. Reflexões sobre conjugalidade violenta na condição moderna. In: Lima FR, Santos C, organizadores. Violência doméstica: vulnerabilidades e desafios na intervenção criminal e multidisciplinar. Rio de Janeiro: Lúmen Júris; 2009. p. 183-194.

21. Azambuja MPR; Nogueira C. Potencialidades investigativas para a violência de gênero: utilização da análise de discurso. Cien Saude Colet 2009; 14 (5):1721-1730.

Apresentado em 29/06/2010

Aprovado em 13/08/2010

Versão final apresentada em 16/09/2010 